\title{
MnO Reduction in High Carbon Ferromanganese Production: Practice and Theory
}

Keywords: ferromanganese, production, mechanisms, theory, reactions, ore

\section{Theresa Coetsee}

e-mail: theresa.coetsee@up.ac.za

Department of Materials Science and Metallurgical Engineering, University of Pretoria, South Africa

\begin{abstract}
The SAF (Submerged Arc Furnace) process is most widely used for industrial production of high carbon ferromanganese. Most plants use ore feed in the form of lump ore $(-75 \mathrm{~mm}+6 \mathrm{~mm})$, but long term supply is limited, and large quantities of ore fines are generated in ore mineral processing. Therefore development of alternative processes using ore fines $(-10 \mathrm{~mm})$ is important. The AlloyStream process is one such process developed to use a feed material mixture of fine ore, coal and flux. This process development provided a unique opportunity to correlate $\mathrm{MnO}$ reduction process theory to pilot plant production practice represented in minerlogical observations furnace heap samples.
\end{abstract}

\section{Introduction}

The AlloyStream process was extensively tested in pilot plant and demonstration plant trials (Coetsee et al., 2015a). Two demonstration plant campaigns were completed, producing 2077 tons HCFeM in the first campaign of 7 months duration and 5014 tons HCFeMn in the second campaign of 11 months duration. The furnace cross section diagram in Figure 1 illustrates the furnace processing zones. In this process the raw material feed mixture $(-10 \mathrm{~mm}$ particle diameter) is fed through the furnace combustion zone (freeboard) onto a liquid alloy bath, forming heaps of reacted material; the heap material is heated at the heap top surface by heat generated from burning combustibles with oxygen enriched air in the freeboard. The combustibles consist of fuel gas, coal volatiles, coal carbon and reduction reaction product gas emanating from the heaps. Final reaction and smelting of the heap material is supported by energy transferred from the induction-heated alloy bath. In addition to the feed materials size requirement differences for the SAF at $-75 \mathrm{~mm}+6 \mathrm{~mm}$ (Habashi, 1997) 
compared to $-10 \mathrm{~mm}$ for the AlloyStream process, additional important distinguishing process features are illustrated in Table I.

Figure 1: Furnace cross-section

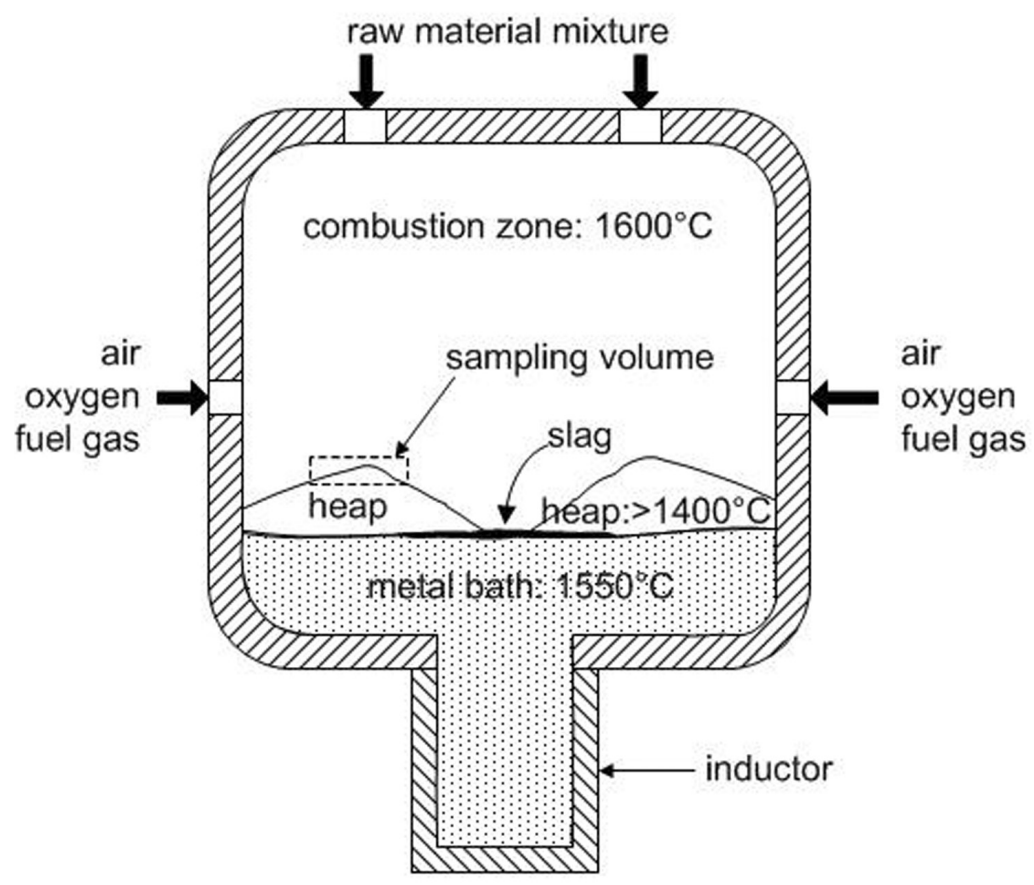

Table I: Main process features: AlloyStream vs. SAF

\begin{tabular}{|l|l|l|}
\hline & \multicolumn{1}{|c|}{ AlloyStream } & \multicolumn{1}{|c|}{ SAF } \\
\hline Ore particles size & $-10 \mathrm{~mm}$ & $-75 \mathrm{~mm}+6 \mathrm{~mm}$ \\
Process energy electrical energy input $(\%)$ & 30 & 100 \\
Carbonate ore in ore mixture $(\%)$ & unlimited & $<30 \%$ \\
Reductant particle size & $-2 \mathrm{~mm}$ & $-75 \mathrm{~mm}+6 \mathrm{~mm}$ \\
Reductant quality and cost & low cost (thermal coal) & high cost (specific requirements) \\
Feed materials reaction temperatures $\left({ }^{\circ} \mathrm{C}\right)$ & $1400^{\circ} \mathrm{C}-1600^{\circ} \mathrm{C}$ & $25^{\circ} \mathrm{C}$ to arc temperature $\left(>2000^{\circ} \mathrm{C}\right)$ \\
Refractory materials & MgO-based & Carbon-based \\
\hline
\end{tabular}

The pilot plant campaign discussed here spanned a period of four months in which more than 400 tonnes of HCFeMn was produced. The ore feed consisted of mixtures of Mamatwan ore and Wessels ore from South Africa. Two ore ratios were tested, $90 \%$ Mamatwan ore to $10 \%$ Wessels ore was fed for 7 weeks (253 tonnes of HCFeMn produced) to test the attainability of $78 \% \mathrm{Mn}$ alloy, and subsequently changing to $75 \%$ Mamatwan ore and 25\% Wessels ore for 9 weeks (123 tonnes of HCFeMn produced) to test the attainability of $76 \% \mathrm{Mn}$ alloy. These target manganese values were selected as per ASTM standard ferromanganese alloy compositions A and B in Table II. Throughout the campaign a medium-volatile thermal coal (from Exxaro's Leeuwpan colliery) was used as 
reductant. Silica sand was added as flux to ensure a sufficiently fluid slag was formed, whilst also maintaining monoxide saturation at $1550^{\circ} \mathrm{C}$ to protect slag line refractories from chemical wear. Typically, the aim slag chemistry used to achieve these objectives was at basicity (\% $\mathrm{CaO}+$ $\% \mathrm{MgO}) / \% \mathrm{SiO}_{2}$ of 1.5 with approximately $25 \% \mathrm{MnO}$ (from an expected $80 \%$ manganese recovery). Details of feed mixture mass balance calculations vs. actual tapped slag chemistries attained are discussed elsewhere (Coetsee et al., 2017).

Table II: Alloy compositions: ASTM specification for standard ferromanganese

\begin{tabular}{|l|l|c|c|c|c|}
\hline & \%Mn & \%C $\max$ & \%Si max & \%P $\max$ & \%S max \\
\hline A & $78.0-82.0$ & 7.5 & 1.2 & 0.35 & 0.05 \\
B & $76.0-78.0$ & 7.5 & 1.2 & 0.35 & 0.05 \\
C & $74.0-76.0$ & 7.5 & 1.2 & 0.35 & 0.05 \\
\hline
\end{tabular}

As part of the wider process development study, heap samples were taken from the furnace with a sampling spoon, accessing the heap through the furnace inspection door. The sample was cooled under nitrogen gas to prevent re-oxidation. The top part of the heap was sampled, within an estimated $200 \mathrm{~mm}$ of the top surface of the heap. The total heap height was $300 \mathrm{~mm}$ to $400 \mathrm{~mm}$. The typical estimated residence time of material in the heap was one hour and the maximum temperature (at the heap surface) was typically $1500^{\circ} \mathrm{C}$. Part of the heap sample was taken apart to separate metal beads out. The metal beads were chemically analysed, using Inductively Coupled Plasma Optical Emission Spectrometry (ICP-OES) and combustion (LECO) analysis for C and S. Another part (cross section) of the heap sample was set in epoxy to prepare a polished section for mineralogical study. Typically, a heap sample was collected every 24 hours, and the metal beads separated out by hand. Only some of the heap samples were prepared as polished sections. The phase chemical composition of the oxide and metal phases in the polished section was analysed by energy-dispersive X-ray spectrometry (EDX). First the polished section was coated with carbon for oxide phase analyses. Subsequently the metal phases were analysed after the carbon coating was removed and re-coating with aluminium was done. Metal analyses were done using wavelengthdispersive X-ray spectrometry (WDX) for C, P, S and Si.

Although the AlloyStream process is of much different configuration to the industrially used Submerged Arc Furnace (SAF) process, and also operated in a relatively narrow range of lower temperatures, insights gained from reduction mechanism questions are of value to all current and future carbothermic manganese reduction processing. As an example, if self reducing pellets are considered as part of the feed mixture, or applied as an option to recover manganese units from ore fines, accurate reduction reaction theory will point to the required optimal processing conditions. 
The following illustrations and analysis of mineralogical observations from these samples highlight the insights gained into the mechanisms of manganese reduction. The objective of this study is to reconcile $\mathrm{MnO}$ carbothermic reduction theory with the practice of high carbon ferromanganese production as represented in the heap sample polished section phase mineralogy. In addition, laboratory experimental results are used to aid in the interpretation.

\section{Previous work and theory}

The most important and thermodynamically difficult process step in HCFeMn production is reduction of $\mathrm{MnO}$ to the final product. This reduction step has been extensively researched in laboratory studies (Koursaris and See, 1979; Eric and Burucu, 1992; Ostrovski and Webb, 1995; Akdogan and Eric, 1995). Industrial scale furnace investigation of this reaction has been reported, using sampling and analysis of the furnace contents after shut-down (Barcza at al., 1979). In all of these laboratory studies two or three distinct reduction stages were identified in the reduction of manganese from different manganese ores. In the rapid first reduction stage the higher oxides of manganese and iron are reduced by $\mathrm{CO}$ to $\mathrm{MnO}$ and $\mathrm{FeO}$ (resulting in approximately $30 \%$ reduction). In the markedly slower second stage of reduction metallisation of $\mathrm{FeO}$ and $\mathrm{MnO}$ starts. Metallisation begins with metallic iron nucleation throughout the reduced ore particle, next to solid monoxide particles within the liquid silicate slag. In Mamatwan ore reduction, the second reduction stage spanned the reduction range of $30 \%-60 \%$ at $1300^{\circ} \mathrm{C}$ and $30-70 \%$ at $1350^{\circ} \mathrm{C}$, and was determined to be most likely under chemical reaction control for the reduction reaction of solid monoxide by $\mathrm{CO}$ gas to $\mathrm{Mn}_{5} \mathrm{C}_{2}$ (Eric and Burucu, 1992).

In the third stage, final reduction of $\mathrm{MnO}$ by carbon occurs. This stage has the lowest reduction rate (Eric and Burucu, 1992), most likely due to the slow diffusion of $\mathrm{Mn}^{2+}$ ions in the monoxide phase, and/or liquid slag phase coating the monoxide phase. In the second and third reduction stages manganese is reduced from the liquid slag phase and from the monoxide solid-solution phase, if the latter is present. In ore of negligible $\mathrm{MgO}$ content, the monoxide phase contains mostly $\mathrm{MnO}$ and the $\mathrm{MnO}$ activity in the monoxide is close to unity. Once manganese reduction has proceeded to the extent that the monoxide is consumed, and only dissolved $\mathrm{MnO}$ in the liquid slag phase remains, the reduction reaction slows dramatically as the $\mathrm{MnO}$ activity decreases (Tangstad and Olsen, 1997).

Reduction of $\mathrm{MnO}$ is generally described as follows:

$(\mathrm{MnO})+<C>=[\mathrm{CO}]+(\mathrm{Mn})$ 
Consisting of the combination of the Boudouard reaction and $\mathrm{MnO}$ reduction by $\mathrm{CO}$ :

$\left[\mathrm{CO}_{2}\right]+<\mathrm{C}>=2[\mathrm{CO}]$

$(\mathrm{MnO})+[\mathrm{CO}]=[\mathrm{CO}]_{2}+(\mathrm{Mn})$

$<>$ = solid; ( ) = liquid; [ ] = gas

However, thermodynamic calculations, assuming unit activities, confirm that $\mathrm{MnO}$ is reduced only in the presence of carbon. Also, mixed carbides of $\mathrm{Mn}$ and Fe may form as reduction reaction products. The minimum temperatures required in the formation of manganese and manganese carbides from reduction of solid $\mathrm{MnO}$ by carbon were calculated in the reaction module of FactSage 6.4. The calculation results are illustrated in Figure 2 , indicating that the required minimum reduction temperature is somewhat lowered when manganese carbides are produced, instead of pure manganese.

Figure 2: Thermodynamic plot of reactions

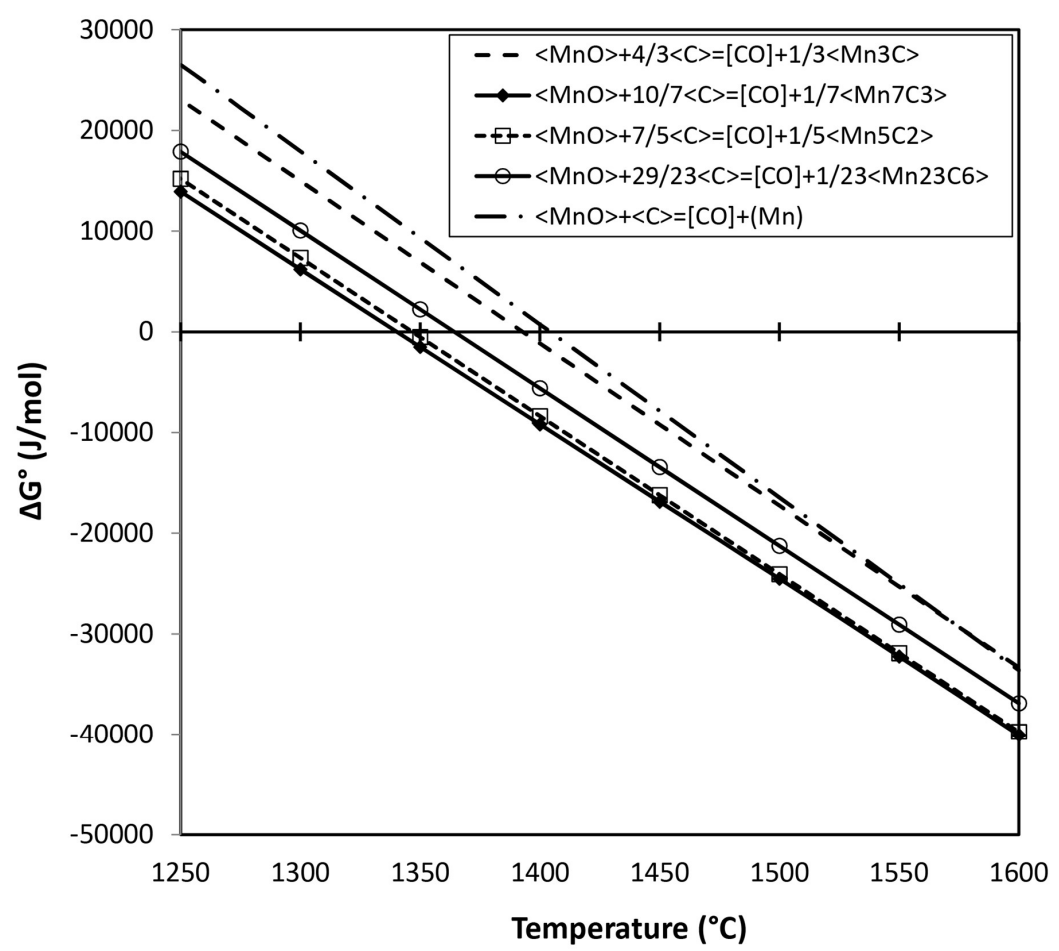

Theoretically then, reduction of solid $\mathrm{MnO}$ to $\mathrm{Mn}$, as per reaction (1), can proceed at temperatures higher than $1403^{\circ} \mathrm{C}$. The minimum temperature required to reduce $\mathrm{MnO}$ to the different manganese carbides is lower, ranging from $1341^{\circ} \mathrm{C}$ for $\mathrm{Mn}_{7} \mathrm{C}_{3}$ formation to $1393^{\circ} \mathrm{C}$ for $\mathrm{Mn}_{3} \mathrm{C}$ formation. From the 
thermodynamic calculations, irrespective of the reaction product being pure manganese or manganese carbides, reduction of $\mathrm{MnO}$ by $\mathrm{CO}$ cannot proceed in the temperature band considered here, $1250^{\circ} \mathrm{C}$ to $1600^{\circ} \mathrm{C}$. However, as will be illustrated from this investigation into the phase composition of heap samples extracted from the AlloyStream pilot plant furnace, simplified thermodynamic calculations as presented in Figure 2 does not accurately represent observed reduction mechanisms accurately.

\section{Results and discussion}

The feed mixture relevant to this study was $71 \%$ ore ( $90 \%$ Mamatwan and $10 \%$ Wessels), $28 \%$ coal, and $1 \%$ silica flux. Ore and coal chemical compositions are summarised in Table III and IV. The following discussion illustrates typical observations made across many heap samples collected over the campaign duration. A polished section made from a typical heap sample is illustrated in Figure 3. The first important observation is the even distribution of bulk phases of dense green oxide areas, shiny metal droplet areas and larger porous black reductant areas. Clearly the ore was easily reduced to $\mathrm{MnO}$ level and beyond, as evidenced by the formation of alloy areas already at the heap surface and the characteristically deep green colour of $\mathrm{MnO}$ in the oxide areas. Temperatures within the top half of the heap was low compared with the temperatures expected in the MnO reduction zone in the SAF.

Figure 3: Typical heap sample polished section (1: green oxide area, 2: porous black reductant area, 3: shiny metal droplet areas)

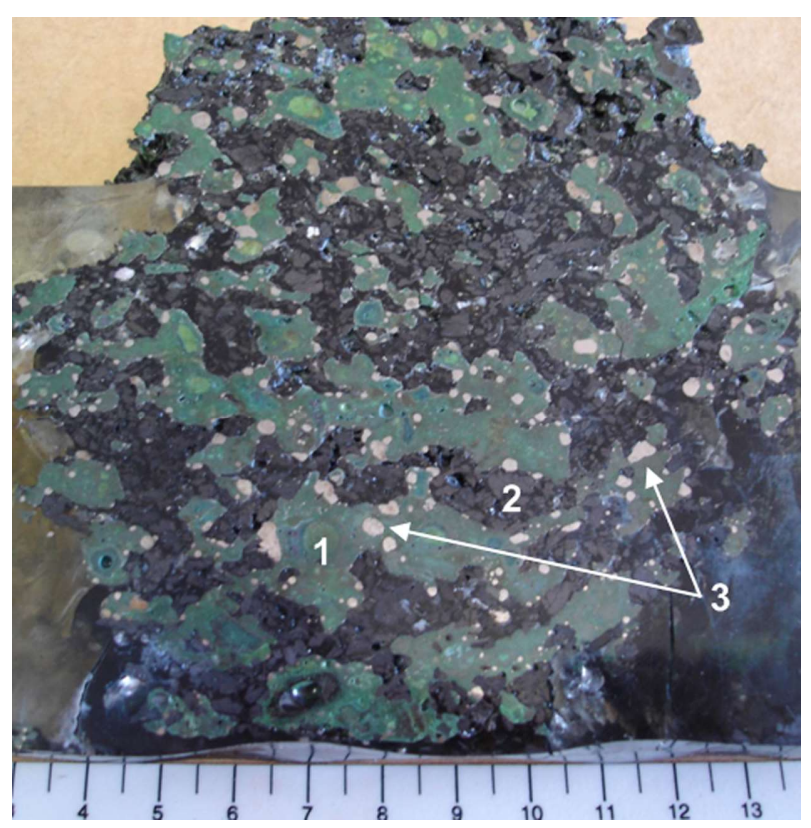


Table III: Bulk composition of manganese ores (mass\%)

\begin{tabular}{|l|c|c|}
\hline & Mamatwan & Wessels \\
\hline $\mathrm{SiO}_{2}$ & 5.10 & 2.00 \\
$\mathrm{Al}_{2} \mathrm{O}_{3}$ & 0.25 & 0.39 \\
$\mathrm{FeO}^{*}$ & 7.6 & 26.2 \\
$\mathrm{TiO}_{2}$ & 0.01 & 0.03 \\
$\mathrm{CaO}$ & 13.30 & 3.99 \\
$\mathrm{MgO}$ & 3.22 & 0.50 \\
$\mathrm{~K} 2 \mathrm{O}$ & 0.11 & 0.02 \\
$\mathrm{MnO} * *$ & 48.9 & 58.7 \\
$\mathrm{P}$ & 0.04 & 0.05 \\
$\mathrm{Ba}$ & 0.11 & 0.81 \\
$\mathrm{Moisture}$ & 0.70 & 0.37 \\
$\mathrm{Total}$ & 79.3 & 93.1 \\
$\mathrm{~B} 2$ & 2.6 & 2.0 \\
$\mathrm{~B} 3$ & 3.2 & 2.2 \\
$\mathrm{Mn} / \mathrm{Fe}$ & 6.4 & 2.2 \\
\hline $\mathrm{B} 2 \% \mathrm{CaO} / \%$ SiO \\
* B3=(\%CaO+\%MgO)/\%SiO \\
*Total iron expressed as FeO; \\
**Total manganese expressed as MnO
\end{tabular}

Table IV: Bulk composition of Leeuwpan coal (mass\%)

\begin{tabular}{|l|c|}
\hline \multicolumn{2}{|l|}{ Proximate analysis (air dried basis) } \\
\hline Moisture & 2.9 \\
Volatile matter & 25.2 \\
Fixed carbon & 56.4 \\
Ash & 15.5 \\
\hline Ultimate analysis (dry basis) \\
\hline C & 70.2 \\
H & 3.61 \\
N & 1.63 \\
O & 7.85 \\
S & 0.68 \\
\hline
\end{tabular}

Shifting from the macro-scale image in Figure 3 to the microscopic scale images in Figure 4, typically observed microscopic phase morphologies can be seen. The chemical composition of individual phase areas in Figure 4 are summarised in Table V and VI. Phase analyses confirmed that the initial metal formed was iron metal prills (about $20 \mu \mathrm{m}$ diameter), with no carbon contained (Coetsee et al., 2015b). Manganese metal is added to the Fe metal prills as $\mathrm{MnO}$ is reduced at the contact areas between iron metal prills and solid $\mathrm{MnO}$, an example is the alloy analysis at position 8 in Figure 4(a) (see Table V). With increased reaction time, more $\mathrm{MnO}$ is reduced and the $\mathrm{Mn}$ content in the alloy prills increased. Generally, the alloy prill carbon content increased with increased $\mathrm{Mn}$ content. As to how the alloy prills' carbon pick-up occurred, this is not certain, but most likely carbon pick-up 
occurred via CO gas decomposition (Koursaris, Kleyenstuber and Finn, 1983). If so, then sufficient porosity within the reduced ore particle must exist to facilitate gas ingress. Alloy beads (larger than prills, up to $1000 \mu \mathrm{m}$ diameter) are mostly observed at the edge of the reduced ore particle, and these beads contain high levels of $\mathrm{Mn}$ and $\mathrm{C}$ (see Table $\mathrm{V}$ for alloy analysis at position 1 in Figure 4(a)). This placement of alloy beads enables increased carbon pick-up via direct contact with reductant particles also positioned at the ore particle surface and/or via CO gas.

Figure 4(a): Photomicrograph of typical microscopic features in heap polished section

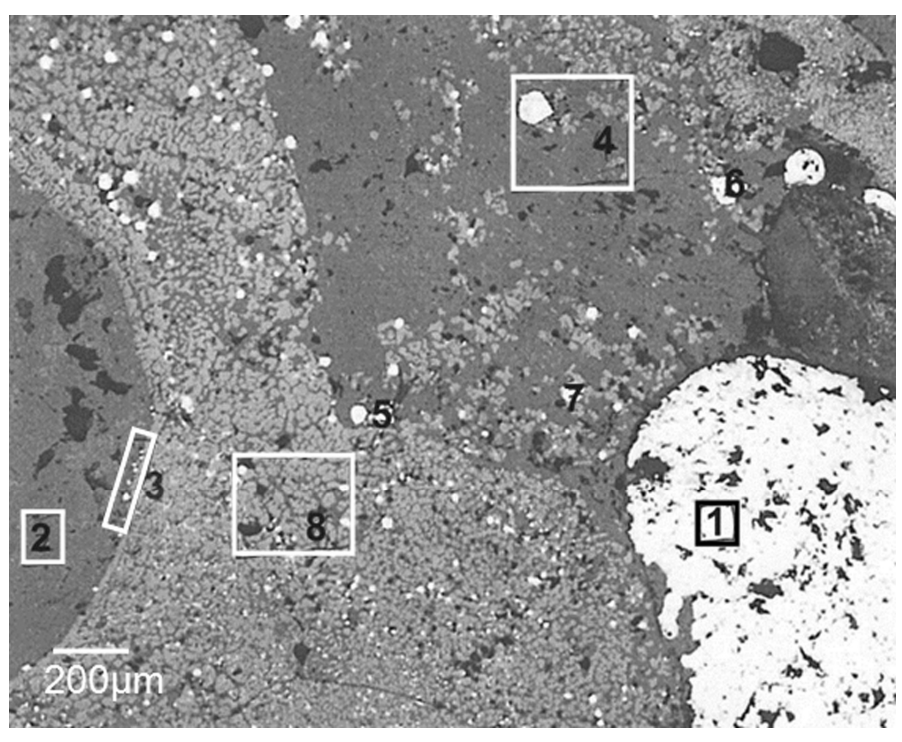

Figure 4(b): Backscattered-electron image of area 4 in Figure 4(a)

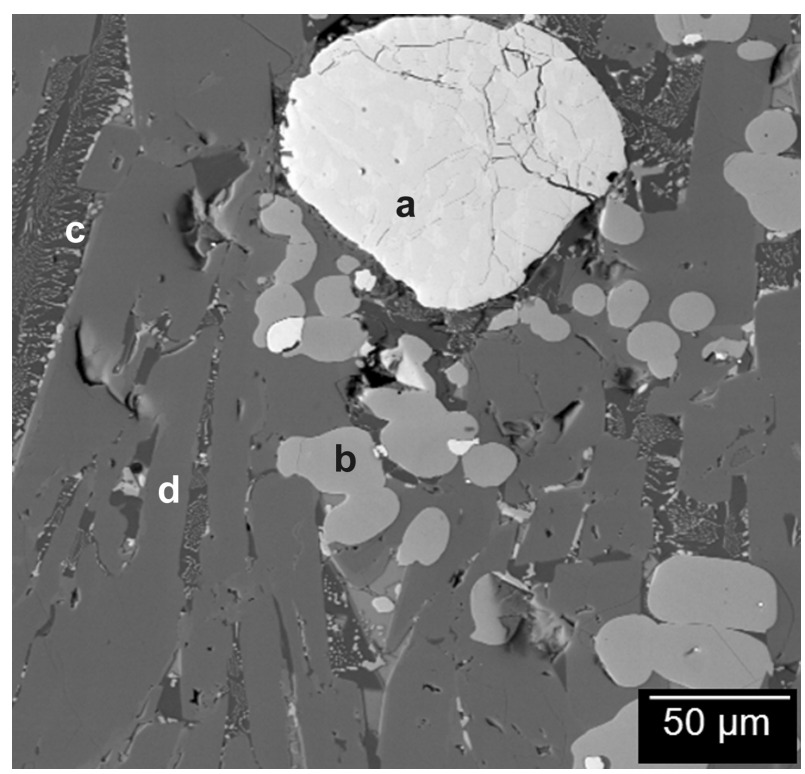


Table V: SEM analyses of alloy phases in Figure 4 (mass\%)

\begin{tabular}{|l|l|l|l|l|l|l|l|l|l|}
\hline Number & ${ }^{3} \% \mathrm{C}$ & $\% \mathrm{Fe}$ & $\% \mathrm{Mn}$ & $\% \mathrm{P}$ & $\% \mathrm{~S}$ & $\% \mathrm{Si}$ & Total & Liquidus & ${ }^{1} \mathrm{PSP}$ \\
\hline 1 & 8 & 17.5 & 74.5 & 0.14 & 0 & 0 & 100. & 1808 & Graphite \\
3 & 6 & 28.1 & 64.8 & 0.11 & 0.12 & 0.13 & 99.3 & 1265 & $\mathrm{M}_{5} \mathrm{C}_{2}$ \\
$4(\mathrm{a})$ & 6 & 34.1 & 61.2 & 0.24 & 0 & 0 & 101. & 1252 & $\mathrm{M}_{5} \mathrm{C}_{2}$ \\
5 & 3 & 53.5 & 43.9 & 0.38 & 0 & 0.04 & 100. & 1129 & ${ }^{2} \mathrm{FCC}$ \\
6 & 5 & 27.2 & 65.1 & 0 & 0 & 0 & 97.3 & 1234 & $\mathrm{M}_{5} \mathrm{C}_{2}$ \\
7 & 2 & 56.9 & 41.2 & 0.30 & 0.03 & 0.09 & 100. & 1212 & $\mathrm{FCC}$ \\
8 & 0 & 63.5 & 35.6 & 0.20 & 0 & 0.04 & 99.3 & 1371 & $\mathrm{FCC}_{3}$ \\
Hand collected & 6.6 & 11.9 & 79.5 & 0.11 & 0.01 & 0.37 & 98.5 & 1307 & $\mathrm{M}_{7} \mathrm{C}_{3}$ \\
Tapped Alloy & 6.7 & 14.5 & 79.6 & 0.10 & 0.00 & 0.01 & 100. & 1304 & $\mathrm{M}_{7} \mathrm{C}_{3}$ \\
\hline
\end{tabular}

${ }^{1}$ PSP $=$ Primary Solidification Phase; ${ }^{2} \mathrm{FCC}=\mathrm{Face}$ Centered Cubic; ${ }^{3} \% \mathrm{C}$ analysis detection linit was $1 \%$.

Table VI: SEM analyses of oxide phases in Figure 4 (mass\%)

\begin{tabular}{|l|l|l|l|l|l|l|l|l|l|l|l|}
\hline Number & $\% \mathrm{Al}_{2} \mathrm{O}_{3}$ & $\% \mathrm{CaO}$ & $\% \mathrm{FeO}$ & $\% \mathrm{MgO}$ & $\% \mathrm{MnO}$ & $\% \mathrm{SiO}_{2}$ & Total & Phase & Liquidus & $\mathrm{B} 3$ & ${ }^{1} \mathrm{PSP}$ \\
\hline 3 & 0 & 2.3 & 0 & 5.1 & 92.9 & 0 & 100.8 & ${ }^{2} \mathrm{SS}$ & & & \\
$4(\mathrm{~b})$ & 0 & 2.0 & 0.5 & 6.8 & 91.0 & 0 & 100.7 & $\mathrm{SS}$ & & & \\
8 & 0 & 2.0 & 0 & 5.0 & 92.9 & 0 & 99.9 & $\mathrm{SS}$ & & & \\
2 & 6.7 & 31.8 & 0 & 3.2 & 28.4 & 28.1 & 98.2 & ${ }^{3}$ Matrix & 1375 & 1.25 & $\mathrm{SS}$ \\
3 & 4.6 & 33.1 & 0 & 3.3 & 30.5 & 28.0 & 99.5 & Matrix & 1491 & 1.30 & $\mathrm{SS}$ \\
4 & 6.5 & 31.2 & 0 & 3.5 & 28.3 & 28.6 & 98.7 & Matrix & 1346 & 1.21 & $\mathrm{SS}$ \\
8 & 5.5 & 33.9 & 0 & 3.6 & 27.0 & 30.0 & 100.0 & Matrix & 1423 & 1.25 & $\mathrm{Ca}_{2} \mathrm{SiO}_{4}$ \\
$4(\mathrm{c})$ & 33.4 & 39.3 & 0 & 0.5 & 3.2 & 22.5 & 99.4 & & & & \\
$4(\mathrm{~d})$ & 0 & 33.4 & 0 & 5.1 & 27.7 & 32.7 & 98.9 & & & & \\
Tapped & 6.8 & 35.5 & 0.1 & 8.8 & 17.2 & 29.0 & 97.4 & Slag & 1536 & 1.53 & $\mathrm{SS}$ \\
\hline
\end{tabular}

${ }^{1} \mathrm{PSP}=$ Primary Solidification Phase; ${ }^{2} \mathrm{SS}=$ Monoxide Solid Solution; ${ }^{3} \mathrm{Matrix}=$ molten silicate background phase;

${ }^{4}$ na=not available; $\mathrm{B3}=(\% \mathrm{CaO}+\% \mathrm{MgO}) / \% \mathrm{SiO}_{2}$

The alloy phase liquidus temperatures (calculated from FactSage 6.4) indicate that alloy areas numbers 3 to 8 were most likely all fully molten at the heap temperature (typically $1400^{\circ} \mathrm{C}$ ).

Therefore, formation of solid manganese-iron carbides seems unlikely because the Fe-Mn-C alloy compositions represent completely molten alloys at $1400^{\circ} \mathrm{C}$. Figure $5(\mathrm{a})$ illustrates the alloy bead and prill analyses in the heap sample at different positions, and Figure 5(b) illustrates corresponding calculated liquidus temperatures, confirming the trends evidenced in Table V. From these trends it is clear that the initial prills contain up to $35 \%$ manganese and no carbon. The liquidus temperatures decrease with increased manganese content, and with carbon content up to $5 \% \mathrm{C}$. Beads contain more than $40 \%$ manganese, and typically more than $5 \% \mathrm{C}$. 
Figure 5(a): Alloy phase composition: Beads and prills in the heap polished section

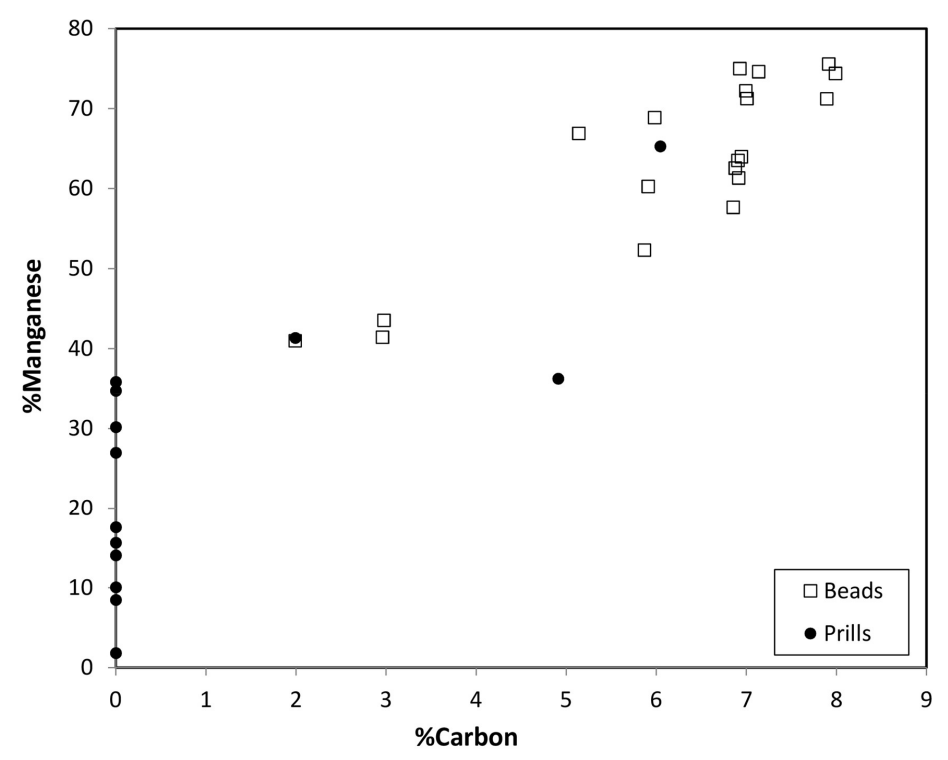

Figure 5(b): Alloy liquidus temperature: Beads and prills in the heap polished section

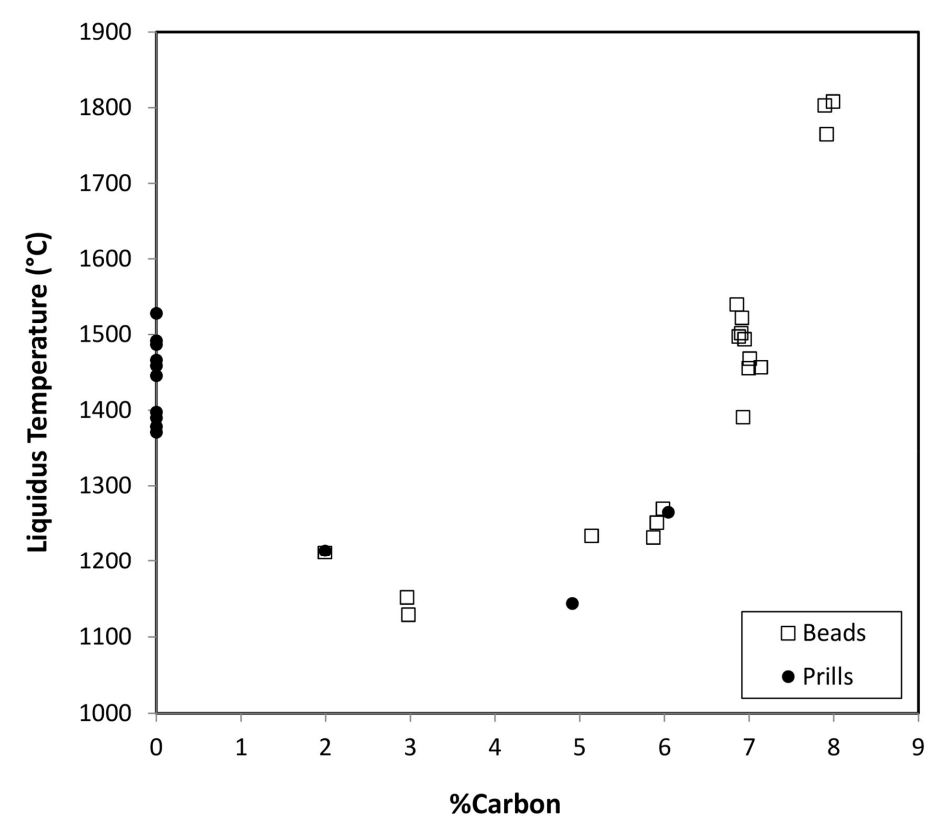

Based on these mineralogical features and phase analyses, the following updated thermodynamic calculations were made, and Figure 2 was updated as displayed in Figure 7. In this calculation the activities of $\mathrm{MnO}$ and $\mathrm{C}$ were retained at one. $\mathrm{MnO}$ activity will be close to unity since the solid solution contains high levels of $\mathrm{MnO}$ (see Table VI for monoxide (ss) phase analyses at positions 3, 4(b) and 8). 
Figure 6: Manganese activity in Fe-Mn-C alloy

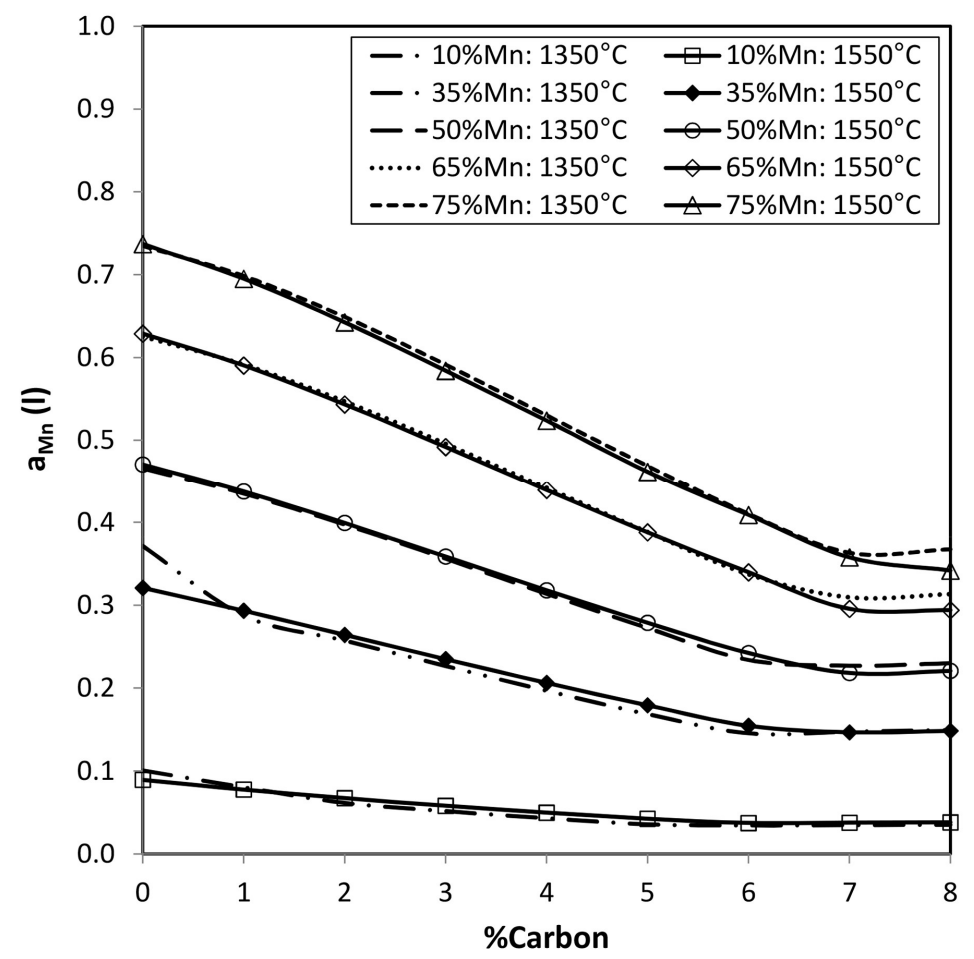

The activity of carbon was retained at unity because of the presence of excess reductant carbon in the reaction system. The activity of manganese in the alloy was lowered to 0.30 based on the following observations based on manganese activity trends in the Fe-Mn-C alloy at $1350^{\circ} \mathrm{C}$ and $1550^{\circ} \mathrm{C}$ as illustrated in Figure 6 . It is clear that manganese activity values are not sensitive to temperature variation between $1350^{\circ} \mathrm{C}$ and $1550^{\circ} \mathrm{C}$ because most of the alloy compositions in Figure 6 are completely molten. In alloys of carbon content above $6 \%$, carbon saturation holds and some graphite is contained in the largely liquid alloy. For alloy compositions in positions 1 to 8 in Figure 4 (see Table $\mathrm{V}$ ) the activity values range in the narrow band of 0.29 to 0.40 . Therefore, Gibbs free energy values were calculated for reduction of solid $\mathrm{MnO}$ by carbon reductant at the lowered manganese activity of 0.30 . Figure 7 illustrates decreased minimum required reduction temperatures due to the decreased activity of manganese in the alloy, from $1403^{\circ} \mathrm{C}$ at unit manganese activity, to $1312^{\circ} \mathrm{C}$ at 0.30 manganese activity. The effect of lowered manganese activity on the minimum required reduction temperature was well explained in a previous study (Braga et al., 2007). 
Figure 7: Updated thermodynamic plot of reactions

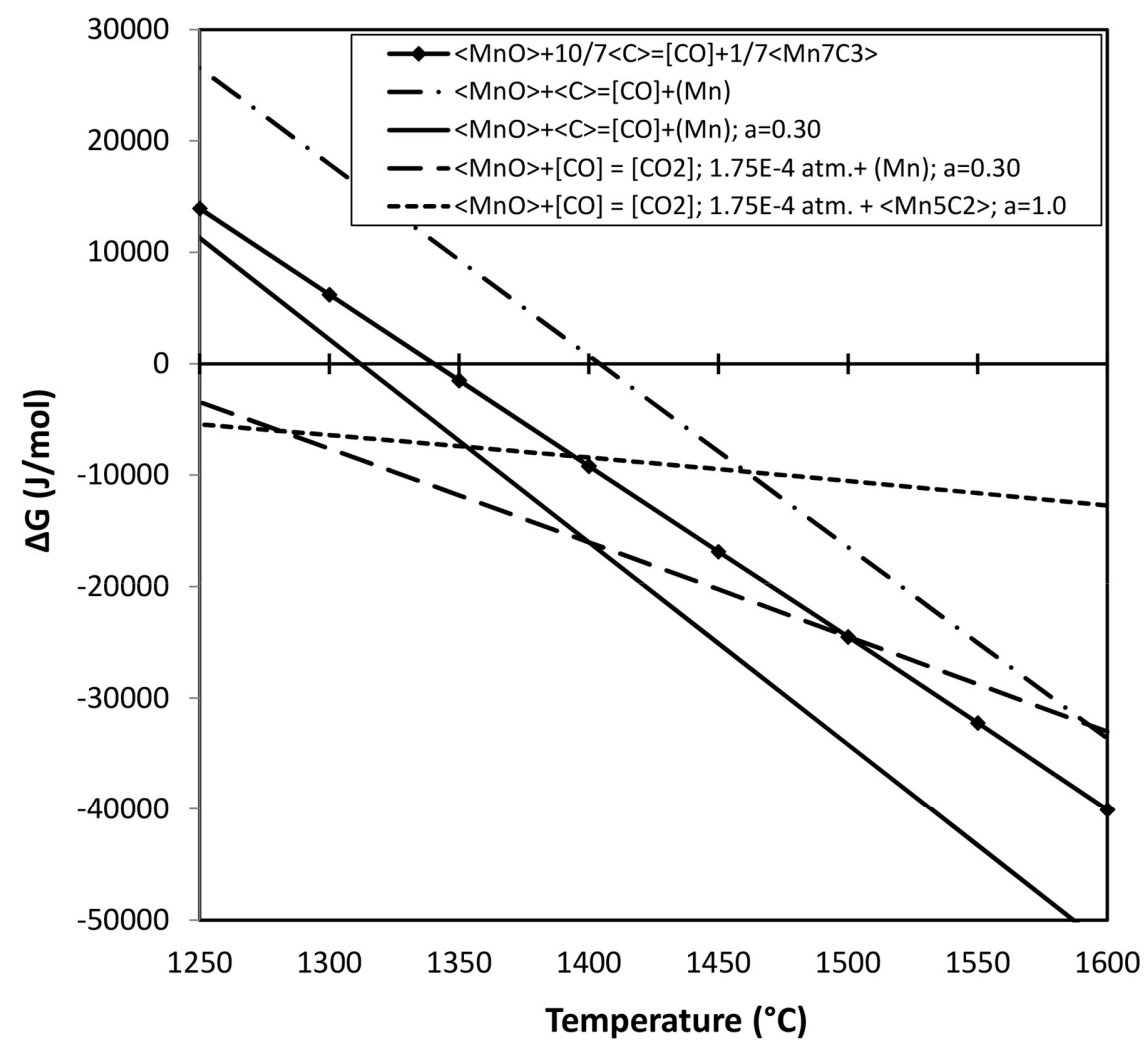

Unit activity of carbon seems to be applicable only in the case of large metal beads, such as at position one in Figure 4(a), which consisted of carbon saturated alloy and also in the case of reduced ore particle surface contact with reductant particles. In the case of metal prills and beads encapsulated in the silicate matrix phase (slag) in the reduced particle interior, carbon reductant contact is unlikely. Reduction of $\mathrm{MnO}$ at these sites is most likely via $\mathrm{CO}$ gas, either directly or from carbon deposition due to the reverse Boudouard reaction. The Gibbs free energy was calculated for pure solid $\mathrm{MnO}$ reduction by $\mathrm{CO}$ gas at 1 atmosphere, according to reaction (4). The activity of manganese was taken as 0.30 as discussed above. The $\mathrm{CO} / \mathrm{CO}_{2}$ ratio is maintained by the Boudouard reaction, therefore the $\mathrm{CO}_{2}$ partial pressure was set to $1.75 \times 10^{-4}$ atmosphere (Boudouard reaction equilibrium at $\left.1400^{\circ} \mathrm{C}\right)$.

$<\mathrm{MnO}>+[\mathrm{CO}]=\left[\mathrm{CO}_{2}\right]+(\mathrm{Mn})$

Figure 7 illustrates that $\mathrm{MnO}$ reduction by $\mathrm{CO}$ gas is possible under such conditions, explaining the formation of Fe-Mn alloy containing significant levels of manganese (35\%Mn) in the absence of direct carbon contact and/or carbon pick-up in the alloy. Similarly, at the lowered $\mathrm{CO}_{2}$ partial 
pressure of $1.75 \times 10^{-4}$ atmosphere, reduction of solid $\mathrm{MnO}$ to $\mathrm{Mn}_{5} \mathrm{C}_{2}$ is possible, but the driving force for this reaction is lower than that for Fe-Mn alloy formation.

These observations and calculations lead to the following conclusions: the main mode of $\mathrm{MnO}$ reduction occurs from reduction of solid monoxide phase areas at the interior of the reduced ore particle (rather than $\mathrm{MnO}$ dissolved in the matrix silicate phase) with $\mathrm{CO}$ gas, so forming the ironmanganese alloy which contains little or no carbon initially. As monoxide reduction proceeds, the manganese content in the iron-manganese alloy increases. The alloy carbon content increases with increases in manganese content. As the metal prills coalesce into beads and beads coalesce into larger beads, these larger beads may move more easily to the surface of the reduced ore particle, where it can contact carbon reductant, resulting in increased levels of carbon in the alloy (close to saturation). Reduction of both monoxide and $\mathrm{MnO}$ dissolved in the silicate matrix may occur at the reduced ore particle-reductant contact areas, but these interfaces are small so that this reaction contribution to overall reduction is likely limited.

To illustrate that the similarity in composition of the tapped alloy and the hand collected alloy beads from heap samples was not incidental to the heap sample discussed here, composition data for several heap and tapped alloy samples are illustrated in Figure 8(a) and (b).

Figure 8(a): Carbon content: Tapped alloy vs. hand collected beads

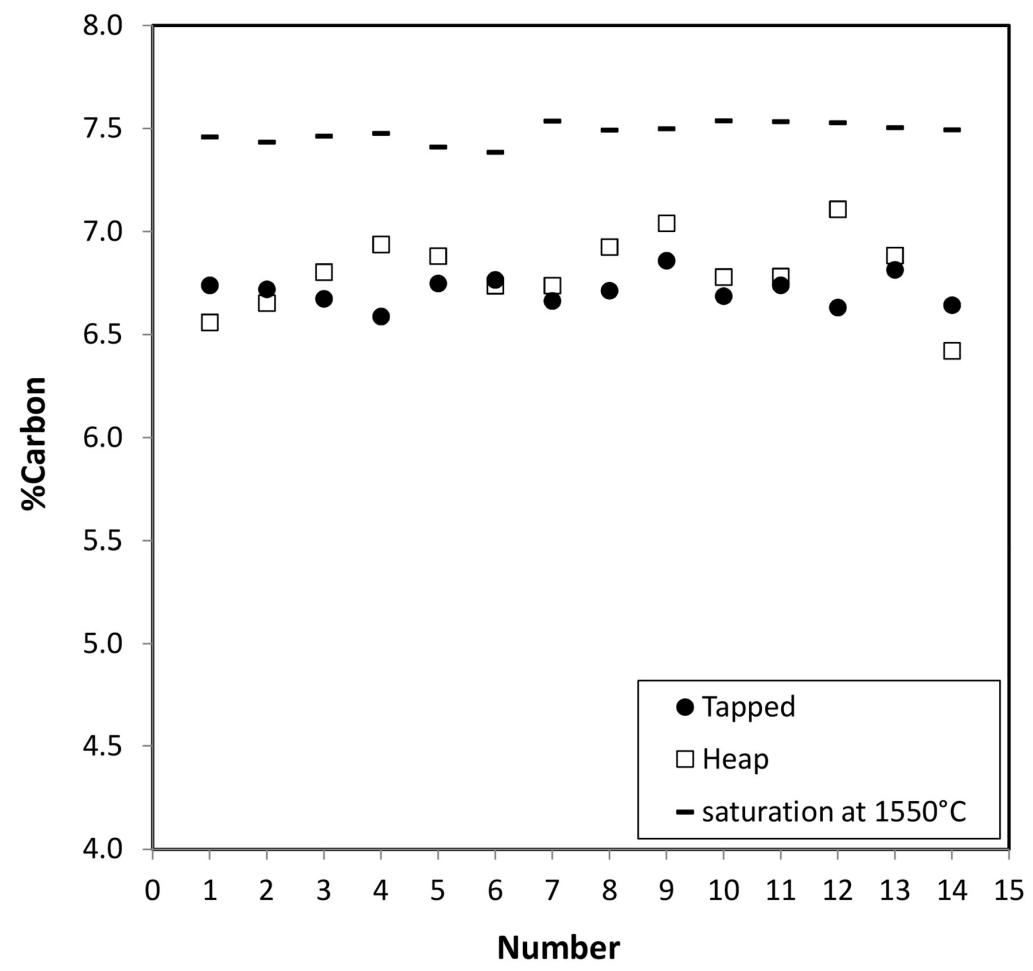


Figure 8(b): Manganese content: Tapped alloy vs. hand collected beads

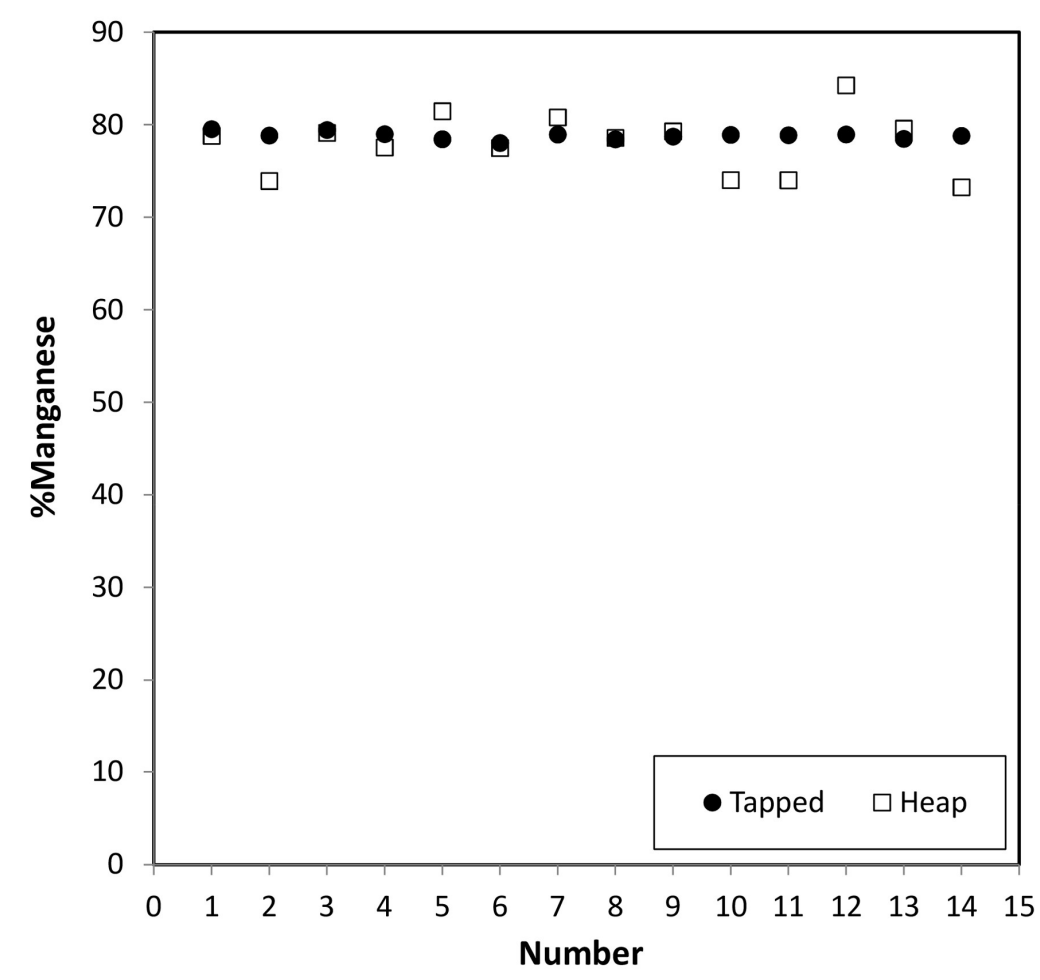

The similarity in chemical compositions indicates that little (if any) modification of alloy bead composition occurred as the feed material mixture moved through the heap volume and melted into the alloy bath. Although the furnace feed mixture contained excess carbon, the alloy product in the heap was not carbon saturated, as illustrated in Figure 8(a), and since an MgO refractory lining was used (as compared to a carbon lining typically used in the SAF) this under-saturation was maintained in the final tapped alloy. This is different to the observations in the SAF, in which a carbon saturated alloy is tapped.

Although the bulk of the furnace feed ore mixture consisted of Mamatwan ore (with high B3 of 3.2), analyses of the silicate matrix phase in heap sample polished sections were of low basicity and seemed similar to each other in composition (see Table VI). Given the high Mamatwan ore basicity, bulk formation of molten silicate at relatively low temperatures of $1400^{\circ} \mathrm{C}$ to $1500^{\circ} \mathrm{C}$ is not expected. Initial silicate melt formation can be better illustrated from laboratory scale experimental results, using only Mamatwan ore in the reaction mixture (Coetsee, 2017).

Figure 9 summarises matrix silicate phase development in Mamatwan ore reacted in a laboratory tube furnace. The tube furnace hot zone temperature was set at $1550^{\circ} \mathrm{C}$. The ore was pre-reduced to MnO level, the reductant was coal char, and silica sand was added as flux to target the bulk end 
point slag composition of $25 \% \mathrm{MnO}$ and $\mathrm{B} 3$ of 1.34 . The difference in time and temperature reaction conditions of the two samples is that one sample was raised into the furnace hot zone over a period of 37 minutes, and then held in the furnace hot zone for another 37 minutes; compared to the other sample which was raised into the furnace over 28 minutes and then removed from the furnace before reaching the furnace hot zone.

Figure 9: Laboratory experiments: matrix phase chemistry development (Filled icons: 0 minutes in hot zone; Open icons: 37 minutes in hot zone) Liquidus temperature bands indicated by icon shapes.

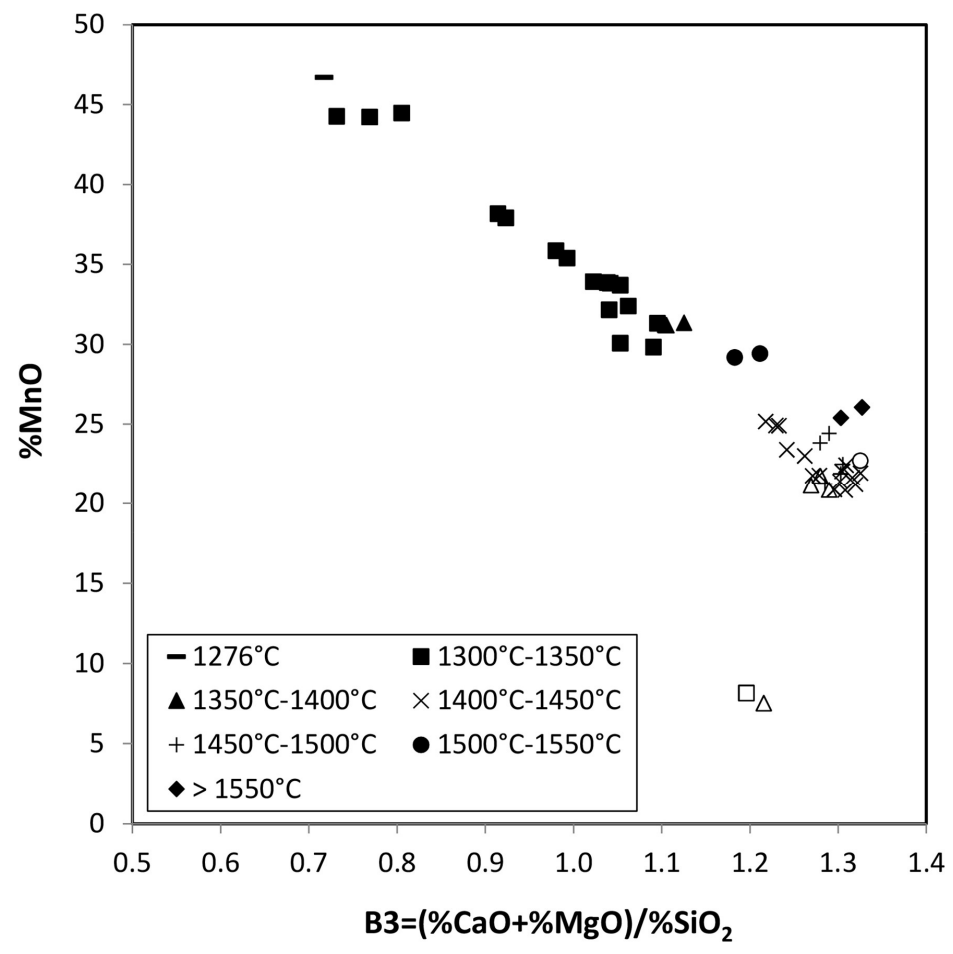

It is clear from Figure 9 that the silicate matrix in the latter sample spans a range of compositions in terms of $\mathrm{B} 3$ and \% $\mathrm{MnO}$ contained. However, most of these composition points were already molten with liquidus temperatures calculated at $1300^{\circ} \mathrm{C}-1350^{\circ} \mathrm{C}$ (see legend in Figure 9). The consequence of this observation is that the initial silicate matrix phase formed in Mamatwan ore is of low melting point relative to the processing temperatures used in HCFeMn production, even though Mamatwan ore is a high basicity ore with high basicity levels (here B3 was 2.7 to 3.2 ). Also, the silicate matrix chemistry quickly converged as illustrated in Figure 9 for the sample reacted for 37 minutes at $1550^{\circ} \mathrm{C}$ furnace hot zone temperature.

These observations indicate that the molten silicate matrix phase formed early on in the reduction process, and most likely closed up any initial porosity in the reduced ore particles, resulting in the 
encapsulation of alloy prills and monoxide phase areas. The extent of encapsulation will determine the level of $\mathrm{CO}$ gas access to the reduced ore particle interior to drive $\mathrm{MnO}$ reduction via $\mathrm{CO}$ gas.

\section{Conclusions}

- The minimum reduction temperature required to reduce $\mathrm{MnO}$ with $\mathrm{C}$ to $\mathrm{Mn}$ in the actual reduction process is not $1403^{\circ} \mathrm{C}$ because the products are not at unit activity. Lowered values of manganese activities and partial $\mathrm{CO}_{2}$ pressures result in lowered minimum reduction temperatures required to reduce $\mathrm{MnO}$ to $\mathrm{Mn}$ (easily as low as $1250^{\circ} \mathrm{C}$ ).

- Reduction of both monoxide and $\mathrm{MnO}$ dissolved in the molten silicate matrix may occur via parallel carbothermic reduction mechanisms: by solid carbon reductant at the reduced ore particle-reductant contact areas, via carbon dissolved in the alloy and via CO gas.

Thermodynamic calculations based on heap sample phase composition measurements illustrate that $\mathrm{MnO}$ reduction by $\mathrm{CO}$ gas (in combination with the Boudouard reaction) is possible in the calculation temperature band of $1250^{\circ} \mathrm{C}-1600^{\circ} \mathrm{C}$.

- The alloy formed in carbothermic reduction of the manganese ore in the heaps was not at the final product alloy composition of HCFeMn. Large alloy beads (hand collected) were of similar analysis than the tapped alloy composition. The alloy tapped from the AlloyStream furnace was not carbon saturated, unlike that typically tapped from a SAF.

- Reduction of $\mathrm{MnO}$ from ore does not require the $\mathrm{MnO}$ to first dissolve into the matrix silicate phase to be subsequently reduced to metal or alloy. This is evidenced by observations made of the phase arrangements in the heap sample polished sections: alloy phase areas were mostly associated with monoxide phase areas with few instances of alloy beads or prills situated in large silicate phase areas.

- Future research should focus on the influence of initial liquid oxide formation on $\mathrm{MnO}$ reduction in different ore types. Experimental investigations should be aimed at unravelling the relative importance and rates of parallel $\mathrm{MnO}$ reduction mechanisms via $\mathrm{CO}$ gas, alloy carbon and direct carbon contact.

\section{Acknowledgements}

The author thanks Exxaro Resources for permission to publish this paper. 


\section{References}

Akdogan, G., Eric, R.H., 1995. Kinetics of the solid-state carbothermic reduction of Wessel manganese ores. Metallurgical and Materials Transactions B, Vol.26B, pp.13-24.

ASTM A99-03(2014), Standard Specification for Ferromanganese, ASTM International, West Conshohocken, PA, 2014, www.astm.org

Barcza, N.A., Koursaris, A., See, J.B., Gericks, W.A., 1979. The 'dig out' of a 75 MVA high-carbon ferromanganese electric smelting furnace. $37^{\text {th }}$ Electric Furnace Conference, Detroit, pp.19-33.

Braga, R.S., Takano, C., Mourao, M.B., 2007. Prereduction of self-reducing pellets of manganese ore. Ironmaking and Steelmaking, Vol.34, pp.279-284.

Coetsee, T., 2017. The effect of processing parameters on ferromanganese alloy carbon content in Mamatwan ore reduction. Mineral Processing and Extractive Metallurgy Review, Vol.38, pp. 116125.

Coetsee, T., Muller, J., Groenewald, J.A., du Toit, A.A., Zeelie, D., 2015a. The AlloyStream process for HCFeMn production. Infacon XIV, Fourteenth International Ferroalloys Congress, Kiev, Ukraine, 31 May-4 June 2015, pp.91-98.

Coetsee, T., Nell, J., Pistorius, P.C., 2017. Phase characterization of high basicity manganese slags. Metallurgical and Materials Transactions B, Vol.48B, pp.1463-1485.

Coetsee, T., Reinke, C., Nell, J., Pistorius, P.C., 2015b. Reduction mechanisms in manganese ore reduction. Metallurgical and Materials Transactions B, Vol.46B, pp.2534-2552.

Eric, R.H., Burucu, E., 1992. The mechanism and kinetics of the carbothermic reduction of Mamatwan manganese ore fines. Minerals Engineering, Vol.5, pp.795-815.

Habashi, F. (ed.), 1997, Hanbook of extractive metallurgy, vol. 1, Weinheim: Wiley-VCH, pp. 420-437. Koursaris, A., Kleyenstuber, A.S.E., Finn, C.W.P., 1983. A mineralogical investigation of the reduction of Mamatwan manganese ore with carbon. Special Publication, Geological Society of South Africa, Vol.7, pp.375-382.

Koursaris, A., See, J.B., 1979. Reactions in the production of high-carbon ferromanganese from Mamatwan ore. Journal of the South African Institute of Mining and Metallurgy, Vol.79, pp. 149-158. 
Ostrovski, O. I., Webb, T.J.M., 1995. Reduction of siliceous manganese ore by graphite. ISIJ International, Vol.35, pp.1331-1339.

Tangstad, M., Olsen, S.E., 1997. Phase relations in ferromanganese slags during melting and reduction. $5^{\text {th }}$ International Conference on Molten Slags, Fluxes and Salts, ISS, Warrendale, pp.549555. 